\title{
Fides in parenthesis: A spirituality of leadership for a (post-)secular(ising) world
}

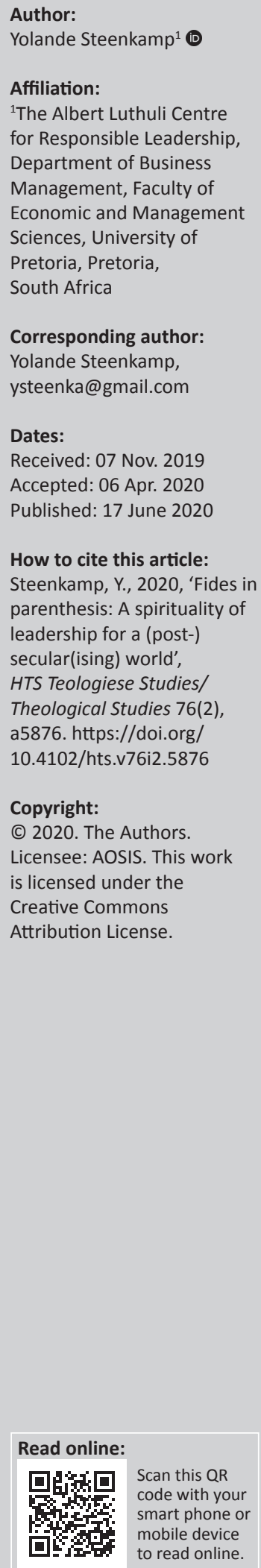

From the viral social media feeds showing Chief Justice Mogoeng Mogoeng in fervent prayer for the nation, to professed Christian Thuli Madonsela's careful expression of the separation between religion and state, faith identity in the public sphere emerges as anything but a straightforward matter. By placing 'Christian' in parenthesis, the 2019 theme of the Theological Society of South Africa conference acknowledged that leaders operate in negotiated spaces and confirmed the complexity of the context in which we attempt to conceptualise leadership from a theological perspective. This raises the question of the role that personal faith convictions play and may be allowed to play in public life. While conceptualising leadership from a faith perspective in a context that is at once secular(ising) and post-secular(ising) may be complex, evidence emerging from leadership studies of the importance of spirituality in leadership necessitates such a reflection. This article considers the problem from a theological point of view, drawing on Schleiermacher and Bonhoeffer's later letters from prison to provide a theological foundation for a public spirituality of leadership.

Keywords: Spirituality of leadership; Anatheism; Post-secular faith; Richard Kearney; Public theology.

\section{Introduction}

The ${ }^{1}$ word 'crisis' featured eight times in the 2019 State of the Nation Address by South African President Cyril Ramaphosa, referring to such diverse situations as violence against women and children (2019:6), the public health system (2019:6,27), sewage and infrastructure (2019:19), and Eskom and its economic consequences (2019:21, 22, 23). It has in fact become rather common to hear commentators use the word 'crisis' when referring to South Africa, whether this refers to the nation's leadership, as in the case of two heads of South African business schools (Mohale 2019; Naudé n.d.:n.p), or her state of governance or the politico-economic situation. These references often result in a call for leadership, and specifically ethical leadership. Speaking at a Responsible Leadership Conference in Stellenbosch in 2017, for instance, then South African President Kgalema Motlanthe described the leadership required to address social development challenges as 'cross-sectorial' and 'ethical' (Country Needs Ethical Leaders 2017:n.p). Similarly, at a gathering of the Business Unity of South Africa (BUSA) following the election of Deputy President Cyril Ramaphosa as the new leader of the African National Congress (ANC), Chamber of Mines Chief Executive Officer (CEO) Roger Baxter said (Cronjé 2017):

We hope to see a renewed focus by the ruling party on responsible and ethical leadership in the national interest across all sectors of the economy and at all levels of society. (n.p.)

Likewise, at the 2018 Chief Financial Officer (CFO) awards, Christine Ramon, AngloGold Ashanti's CFO, who was awarded four of the 10 awards for the evening, described our context as 'a time for ethical leadership'.

The religious sector has also added its voice to this call for ethical leadership, either through religious leaders, including ecumenical bodies, or through public figures commenting on their own faith convictions. As an example of the former, the South African Council of Churches has engaged the South African government regarding corruption and the leadership crisis (see eNCA 2016; eNCA 2017; Madia 2017; Mahlase 2018; and Nhlabathi 2017). As for public figures, we may 1.This article is based on a section of the PhD thesis by Steenkamp 2016.

2.For another example of public commentators addressing ethical leadership, see Mali (2018:n.p.). For academic contributions, see Schoeman (2014) and Iheriohanma and Oguoma (2010:409-416), whose study refers to the whole of Africa. 
begin with former South African Public Protector, Thuli Madonsela, who reflected on the role of faith in society from the perspective of her own leadership role during the dark leadership days of the then President Jacob Zuma (Pillay 2016). In this, she commented both on the subjective element of faith, noting how she had to 'dig deep into her spiritual reserves' and how countless people supported her through sending spiritual texts, and on the objective contribution of religion towards shared societal values and social cohesion (Pillay 2016). Furthermore, in his 2017 Christmas sermon as well, Anglican Archbishop Thabo Makgoba (2017) spoke boldly about challenging the ANC leadership to re-establish 'values-based, ethical and moral leadership':

All through Advent the prophets have reminded us that the Coming Child challenges us to imagine the near impossible and, in the face of dire realities, to choose life. That is precisely why in recent weeks I have been challenging the leaders of our country to put the common good above all else. I have told the new ANC leadership that the faith community will support their efforts but only on the strict condition that they must work together to re-establish values-based, ethical and moral leadership. (n.p.)

Finally, in mid-2018, a video went viral on Facebook, ${ }^{3}$ showing Chief Justice Mogoeng Mogoeng, who has become somewhat known for his calls for ethical leadership, in fervent prayer for leaders of integrity to be elected to positions of responsibility. ${ }^{4}$ Somewhat earlier, in 2016, Raborife (2016) reported on Mogoeng's address at the Gordon Institute of Business Science:

\begin{abstract}
Mogoeng said it was important for leaders, both in the public and the private sector, to espouse the characteristics of ethical leadership to ensure that the country moved forward in a direction which sought to undo the wrongs of the past. 'We are where we are as a result of what unethical leadership did to us as a nation', Mogoeng said. (n.p.)
\end{abstract}

South Africa, a secular democracy that protects freedom of religion in the constitution, has a profoundly religious population, with Christianity representing the largest sector. In such a religious context, amidst a careful separation between religion and state, the question of the role of spirituality in leadership is one that cannot be avoided, and that calls for theological reflection. This is especially so considering the repeated calls for ethical leadership in the troubled South African context, given the role of religion in providing shared values. Yet, faith identity in the public sphere is anything but a straightforward matter, and deserves a theological response. In 2019, the theme of the Theological Society of South Africa (TSSA) Conference held in Pretoria was 'The last shall be first': Theological and ethical reflection on (Christian) leadership. By placing 'Christian' in parenthesis, the conference theme acknowledged that leaders operate in negotiated spaces, and confirmed the complexity of the

3.See https://www.facebook.com/kwazitheo/videos/1749243981830760/?hc ref ARSOuUemtIPhzVQBGV81bFpWWJtVvyO8ulbICMhYdq15nFq-ovLnfiBTFp LWkpLTVKU\&fref=nf.

4.For more calls for ethical leadership from the religious sector, see McCauley (2016) context in which we attempt to conceptualise leadership from a theological perspective. This raises the question of the role that personal faith convictions play and may be allowed to play in public life. While conceptualising leadership from a faith perspective in a context that is at once secular(ising) and post-secular(ising) may be complex, evidence emerging from leadership studies of the importance of spirituality in leadership necessitates such a reflection.

After exploring the broader theme of spirituality and leadership, the article will provide a brief description of anatheism, the term coined by Irish philosopher Richard Kearney. Read in relation to Kearney's philosophy of religion that described God as possibility, anatheism describes the time 'after' religion, where God may ironically be found again, as a time when the Kingdom becomes a possibility in the world. As such, the presence of God in the world becomes the powerless possible: the story of a vulnerable God, and a story with an uncertain outcome. The overview of anatheism as a means of conceptualising the place of religion in the (post) secular(ising) world will provide the foundation for the following section, which will turn to Bonhoeffer's description of believers given completely to the world as a theological account of Kearney's philosophy of religion. Theologically, then, Kearney's perspective of God as the Powerless Possible is expressed through the creative suffering of God (drawing from Fiddes 1992), which contributes to our understanding of a vulnerable God. We turn now to the first section, which considers the place of spirituality in leadership studies, as sketched by critical scholarship.

\section{Leadership and spirituality}

Research has shown that leaders who incorporate and embody values that are considered to be spiritual ideals (e.g. integrity, honesty, humility, respect, appreciation and personal reflection) display leadership success (Daft 2015:448). Laura Reave's 2005 review of 150 studies found a clear and consistent positive correlation between spiritual values and practices on the one hand and effective leadership on the other. This leadership style does not necessarily point to formal spirituality programmes (Daft 2015:450), but rather describes 'the display of values, attitudes, and behaviors necessary to intrinsically motivate oneself and others toward a sense of spiritual expression through calling and membership.' Daft (2015) further states that:

[S]piritual leaders start by creating a vision through which organization participants experience a sense of calling that gives meaning to their work. ... Second, spiritual leaders establish a corporate culture based on altruistic love. ... Spiritual leaders also engage hope and faith to help the organization achieve desired outcomes. Faith is demonstrated through action.... A leader's hope/faith includes perseverance, endurance, stretch goals, and a clear expectation of victory through effort. (p. 450) 
What is commonly referred to as 'spiritual leadership', ${ }^{5}$ I would term a spirituality of leadership, mainly to distinguish it from leadership roles defined in certain religious or spiritual institutions, which may take any number of forms and is not my interest here. Organised religion is also not necessarily the source of spirituality or an imagination of the sacred, for which I will follow Enblem's definition of spirituality as 'a personal life principle which animates a transcendent quality of relationship to God' (1992:45), ${ }^{6}$ but with the proviso that 'God' in that definition remains free of any interpretive projections based on any one religion or spiritual tradition.

What is important in a spirituality of leadership is the definitive place of demonstrated ethics, that is, the fact that the leader articulates an inspiring vision through both word and action (Reave 2005:657). Indeed (Geaney n.d.):

Many leadership consultants and researchers have written about the practices and processes of spirituality and leadership using terms such as spirit, whole-person, whole-soul, spiritual and most recently engaging leadership. (p. 1)

This could, of course, apply to leaders who would not necessarily subjectively identify as 'spiritual', but may still be experienced and described as such by followers who feel inspired by the qualities embodied by the leader. On the contrary, leaders who profess to be 'spiritual' may not be evaluated as such by their respective followers. As such, then, a spirituality of leadership focuses on 'traditional spiritual values and behavior as related to measures of leadership effectiveness rather than spiritual faith or intention' (Reave 2005:657).

Fry (2003) has identified 'calling' and 'membership' as two core dimensions of spiritual leadership. He describes the sense of calling as the experience of transcendence or how one makes a difference through service to others and, in doing so, derives meaning and purpose in life' (2003:703). As such, the sense of calling explains the leader's motivation, while 'membership' speaks to the leader's ability to successfully create an organisational culture based on altruistic love, 'whereby leaders and followers have genuine care, concern, and appreciation for both self and others, thereby producing a sense of membership and [feeling] understood and appreciated' (Fry 2003:695).

\section{According to Reave (2005):}

Instead of starting with the leader's own vision, which may be flawed, a theory of spiritual leadership would start with the leader's own ethics and integrity. Next the leader's practices should be examined to see if they are truly in line with

5.Servant leadership can be seen as an example of a spirituality of leadership. While it has its origin in Christianity and is often expounded in the context of the leadership of religious institutions, this is not a necessary confinement because it is based on universal spiritual values such as humility and integrity. While servant leadership is more accurately understood as a philosophy rather than a fully developed theory of leadership (Barnett n.d.:n.p.), in a just-published article Mookgo Kgatle argued strongly for servant leadership as a way to address the dire state of polit
leadership in South Africa, characterised by its abuse of power (2018:1-9).

6. Enblem defines 'religiousness', in turn, as 'a system of organized beliefs and worship which a person practices' (1992:45). the values professed. This theory incorporates both the trait approach and the behavioral approach. (p. 663)

For now, let us close this brief overview of the relationship between moral leadership, values-based leadership and spirituality of leadership by considering what we may gain by reflecting on leadership from this perspective. Firstly (Reave 2005):

Examining the relationship between spirituality and leadership can give us valuable insight into leader motivation as well as follower perceptions, motivation, retention, ethics, and performance. (p. 680)

\section{Also (Reave 2005):}

Because most of the spiritual qualities and practices presented here have been universally endorsed as important, positive leader traits and behaviors, further exploration of the relationship between spirituality and leadership can provide us with a springboard for developing a leadership theory that integrates character and behavior, motivation and performance, in a crosscultural model. (p. 681)

From the above, it is clear that empirical studies have confirmed the positive role of spirituality in leadership. This brings us to the question of how this role is to be affirmed in a secular context, where the spiritual or religious life of an individual is considered irrelevant to his or her public roles and engagements. To consider how spirituality of leadership might address this point, we turn to Richard Kearney's philosophy of religion as an entry point for conceptualising the place of the sacred in a (post)secular(ising) world.

\section{Kearney's anatheism}

What is anatheism, or God again - 'ana'? Irish philosopher Richard Kearney uses this word, which he invented for this purpose, to describe that manner of faith that endures the disenchantment of traditional religion (see Kearney 2009, 2011). This is the more personal application of the term, and it will be my focus in this article. Philosophically, it may also be distinguished as an orientation to the enduring Godquestion - one that both takes seriously the critiques of ontotheology and yet embraces the images, metaphors, prayers and dialogues inherited from the tradition that may inform a religious phenomenology of the sacred. Kearney, following Ricoeur, regards the atheistic critique of the traditional God of onto-theology as a necessary moment without which genuine faith cannot develop. For human persons to move to an encounter with what is truly transcendent, they must first allow for the death of those gods made in human image to address hidden and suppressed fears and dependencies (2009:167). Religion is therefore to welcome the contribution of the masters of suspicion who exposed religion's forging of gods in the human image. Many proceed through this death of the fetishised God and remain within an atheistic orientation, forever separating themselves from any notion of the divine. Kearney notes, however, that many find themselves returning to God. 'Anxious souls may ask', 
to adopt Bonhoeffer's phrase, about ways to continue being in the presence of God even after the death of God. Here, 'ana' denotes this return, this finding oneself once again occupied with God, 'after' God. Yet, this can never be the same faith, having moved through the crucible of doubt and critique, the former god-images having been exposed for their self-serving intentions.

Having suffered the death of idolised god-images, the anatheist receives God back again ('ana') as a gift, through fleeting moments of radical hospitality to the stranger. It is during these momentary witnesses, during which the guest unexpectedly becomes the host, that the Divine shines through as witness to the eternal, the excess, the more, which has always already gone, and yet is always already here and always yet to arrive. To read anatheism in this way is to bring it into dialogue with Kearney's earlier philosophical project, namely, to construct a phenomenological hermeneutics of religion (2001; cf. 2018:318). Kearney's response to the problematised God of onto-theology is to reimagine God not as pure being, but as the possibility to be. In this, Kearney limits himself to asking the God-question from the human perspective, or God 'for us'. This precludes the question of the objective existence or non-existence of God, asking instead how God might be God in our world. How might the Kingdom come, in other words? To answer this, he attempts an imaginative rereading of tradition, exploring countertraditions that imagine God in terms of possibility to propose a decidedly ethical foundation for his hermeneutics of religion (Kearney 2001). The God of posse, or possibility, might be God for us only if we enable God through acts of love and kindness to the widow, the orphan and the stranger. This is a preferential option for a God of small things rather than a God of power and might - a God who is vulnerable to human choice and decision, yet a God whose voice forever calls the human imagination to new possible worlds where the Kingdom might come.

Anatheism, when read in dialogue with Kearney's larger philosophical project surrounding the God of possibility, may become a means to conceptualise the place of the sacred in the (post)secular(ising) world. This will become clearer when interpreted theologically with the help of Bonhoeffer, but the core of this potential for the secular lies in anatheism's irony that it is precisely in the absence of God that we may discover God as already present through small acts of kindness in the world.

\section{A vulnerable God, a powerless possible, an uncertain outcome: Bonhoeffer and the God pushed aside $^{7}$}

From this philosophical foundation, we can now turn to a theological expression of God's presence in and through

\footnotetext{
7.This section has been adapted from the author's doctoral thesis (Steenkamp 2016:220-226, 258). This work was completed under the supervien P. Veldsman from the Department of Systematic and Historical Theology at the Faculty of Theology and Religion at the University of Pretoria, South Africa. The title of the thesis was 'Post-metaphysical God-talk and its implications for Christian Theology: sin and salvation in view of Richard Kearney's God Who May Be'.
}

God's very expulsion from the world. The absolute, impassible God of Greek metaphysics has been subjected to increasing theological reinterpretation. This section wishes to bring Kearney's notion of a God Who May Be, who is vulnerable to human response and who is a 'God of small things', into theological focus. We will focus on recent contributions surrounding, especially, the suffering of God on the cross - the event of divine vulnerability par excellence. Indeed, nothing draws a line across the easy and cheerful romanticism of progress like the cross of the Man from Nazareth. It is through suffering and vulnerability that Jesus becomes the Man 'for others', the exemplary, 'last' Man who embodies the eschatological future of humanity as beingfor-O/other (Ratzinger 2004:n.p.). ${ }^{8}$

Paul Fiddes has significantly contributed to the notion of a vulnerable God in his The Creative Suffering of God, where he insists that we remain conscious of the fact that, when we think of God, we think of One who has experienced death, yet without being dead, thereby overcoming non-being (Fiddes 1992:265). Building from Abelard's notion of the intrinsic necessity in God of acting in fidelity to God's own nature, and following the Barthian axiom of the freedom of God, ${ }^{9}$ Fiddes describes God on the cross by arguing that, '(i)n his freedom, God has chosen to empty himself in the incarnation, reaching a climax of humility in Christ on the cross' (Mulcahy 2007:185). This brings him to his argument of God making Godself vulnerable to humanity, by the freedom of God's choice (Fiddes 1989):

But if we take seriously the freedom of God to love, then we can say that he desires fellowship with us, and that by his own eternal choice his being is enhanced by relationship with us. (p.159)

\section{Mulcahy (2007; cf. Fiddes 1989:159) comments:}

Paradoxical though it may seem, human beings can 'add' something to God, can increase God's joy. In other words, through love, creation must be able to 'affect' God, in some way. There is no question of external necessity here. God has no need of human affection or relationship, but out the [sic] freedom of his love God 'determines to be in need'. (p. 185)

This vulnerability runs both ways, however, because humans cannot but be affected by such a revelation of love in the person of Christ. God's total and complete identification with 'a desolate and condemned human being dying outside the city walls on Calvary' demonstrates the 'value and significance humanity has in God's eyes' (Mulcahy 2007:185). Fiddes follows Abelard here, for this demonstration of God's love for humanity elicits a similar response in the human person as the receiver of this love (Mulcahy 2007:185). To a

8.Ratzinger elaborates, 'For to be the man for others, the man who is open and thereby opens up a new beginning, means being the man in the sacrifice, sacrificed man. The future of man hangs on the Cross - the redemption of man is the Cross. And he can only come to himself by letting the walls of his existence be broken down by looking on him who has been pierced (In 19:37), and by following him who as the pierced and opened one has opened the path into the future'.

9.Abelard, in his theory of the atonement, wanted to safeguard God against any extrinsic necessity in the economy of salvation (such as the idea that a ransom had to be paid to the devil, etc.), insisting that the only necessity the divine nature is to be paid to the devil, etc.), insisting that the only necessity the divine nature is
bound to is that of acting in accordance with God's own nature, which is love (see Steenkamp 2016:214-218; cf. also Mulcahy 2007:185). 
large extent, this openness of humanity to be impacted by the illustration of God's love in Christ facilitates our salvation, enabling us to 'accept that we are accepted' (Fiddes draws here from Tillich 1968:202-203, 239-243). According to Mulcahy (2007; cf. Fiddes 1989:159):

Because God in Christ now knows us 'from the inside', because he has entered the furthermost point away from God in identifying with a forsaken dying man, we have the courage to believe that we are really acceptable in his sight. Such acceptance is an integral dimension of what it means to be 'saved'. (pp. 185-186)

For Fiddes, this forms part of the larger question that orients his work on the atonement: how does the past act of salvation in Christ become an immediate presence to the believer? How, then, does God's revelation of love in Christ become a communication of the very Being of God, that is, love, to the believer? Fiddes draws from both Schleiermacher and Bonhoeffer in answering this question. From Schleiermacher, he appropriates the idea that the presence of the Saviour dwells in the community of believers, through which this presence holds 'a transforming power over human attitudes towards God' (Mulcahy 2007:186). Practically, this means that humanity's broken God-consciousness becomes transformed through the perfect God-consciousness of Jesus Christ that he communicates to his disciples (Fiddes 1989:161-162; cf. Mulcahy 2007:168-169). The conclusion that Fiddes draws from this is that Christ, whose presence is able to influence and transform personalities, 'must bring about a new kind of "corporate life" between himself and those whom he transforms, and also between those who are seized by his influence' (Fiddes 1989:162; cf. Mulcahy 2007:187).

Fiddes now turns to two aspects of Bonhoeffer's thinking to bring balance to this insight of Schleiermacher. Firstly, Bonhoeffer's emphasis on the suffering God serves as a corrective to Schleiermacher's Jesus whose 'communion with the Father is untouched by pain and suffering' and who 'goes into death with trusting and serenity'. Secondly, Bonhoeffer's interpretation of Jesus' experience of God-forsakenness on the cross serves as a corrective to Schleiermacher's confidence in a 'universal' religious experience that seems at odds with a contemporary sense of the loss of God-consciousness (Mulcahy 2007:187).

Bonhoeffer, like Schleiermacher, understood Christ's presence to dwell in the community of believers. Unlike Schleiermacher, however, Bonhoeffer did not identify the Church as the presence of Christ with the glorified Christ at the right hand of the Father, but rather with the humiliated Christ on the cross. In his prison letters, Bonhoeffer enlarged his understanding of Christ's presence to include all life in all of the world, including even the secular world that lives in ignorance of God (Fiddes 1989:164; cf. Mulcahy 2007:188). ${ }^{10}$

10.During his time in prison, Bonhoeffer indeed began to perceive the world as livin in ignorance of God: 'The thing that keeps coming back to me is, what is Christianity, and indeed what is Christ, for us to-day? The time when men could be told everything by means of words, whether theological or simply pious, is over, and so is the time of inwardness and conscience, which is to say the time of religion as such. We are proceeding towards a time of no religion at all: men as they are now simply cannot be religious any more.... Our whole nineteen-hundred-year-old
Bonhoeffer accomplishes this by linking Christ's experience of abandonment on the cross with the contemporary loss of a sense of God. That God revealed Godself as Deus absconditus through a scorned human being who felt himself abandoned by his heavenly Father denotes a God who reveals Godself in weakness (Mulcahy 2007:188). This means not only that God suffers with the destitute and forsaken but also that (Fiddes 1989):

God is 'there for us' in places where he appears to be redundant, where no one calls for a God to intervene, where human beings are exercising their freedom to be adult. There God suffers his humiliation, crucified 'at the hands of the world'. (p. 165)

Contemporary Christians, in Bonhoeffer's view, are called to engage with the secular world in a radically different way. In several of his letters from prison, he ponders at length the nature of what he calls a 'religionless Christianity', and in the end comes to value how, in the secular world, God is not pushed aside to the fringes, to that which humanity cannot control or understand, and therefore seeks a god-of-the-gaps that may complete these borderline experiences of humanity. Because the secular world has done away with God altogether, the Deus absconditus is able to be present in the very centre of human life. In order for Christians to testify to this, they must themselves be, with conviction, in the world (Bonhoeffer 1959):

$[L]$ ike Christ himself ('My God, my God, why hast thou forsaken me?') he must drink the earthly cup to the lees, and only in his doing that is the crucified and risen Lord with him, and he crucified and risen with Christ. This world must not be prematurely written off. (p. 154)

If God is then willing in God's great love to be pushed aside by the world, so must the contemporary Christian learn to follow in the way of the seemingly invisible, seemingly absent. This is the way of the Church who corporately bears witness to the presence of Christ in the world, while the secular world lives in ignorance of this presence (Bonhoeffer 1959):

God is teaching us that we must live as men who can get along very well without him. The God who is with us is the God who forsakes us (Mark 15.34). The God who makes us live in this world without using him as a working hypothesis is the God before whom we are ever standing. Before God and with him we live without God. God allows himself to be edged out of the world and on to the cross. God is weak and powerless in the

Christian preaching and theol............................................................ we call Christianity has always been a pattern - perhaps a true pattern - of religion. But if one day it becomes apparent that this a priori "premise" simply does not But if one day it becomes apparent that this a priori "premise" simply does not exist, but was an historical and temporary form of human self-expression, i.e., if we
reach the stage of being radically without religion - and I think this is more or less reach the stage of being radically without religion - and I think this is more or less
the case already, else how is it, for instance, that this war, unlike any of those before it, is not calling forth any "religious" reaction? - what does that mean for "Christianity"?' (Bonhoeffer 1959:122).

In this context Bonhoeffer asked, 'If religion is no more than the garment of Christianity ... then what is a religionless Christianity?' (Bonhoeffer 1959:123). It becomes clear, then, that Bonhoeffer had to broaden his understanding of the presence of Christ to include the secular world and not only the Church because he saw the world changing in front of his eyes into a world where the presence of 'Church' to a secular person in a religionless world becomes largely irrelevant. 'Church' to a secular person in a religionless world becomes largely irrelevant. 'How do we speak', he asks, 'of God without religion, i.e. without the temporally influenced presuppositions of metaphysics, inwardness, and so on? ... In what way are we in a religionless and secular sense Christians, in what way are we the Ekklesia, "those who are called forth, not conceiving of ourselves religiously as specially favoured, but as wholly belonging to the world? Then Christ is no longer
an object of religion, but something quite different, indeed and in truth the Lord of the world' (Bonhoeffer 1959:123). 
world, and that is exactly the way, the only way, in which he can be with us and help us. Matthew 8.17 makes it crystal clear that it is not by his omnipotence that Christ helps us, but by his weakness and suffering. (p. 164)

These words of Bonhoeffer are perhaps as close as we have come to a theological formulation of Kearney's emphasis on a powerless and vulnerable God. Bonhoeffer even expresses, in the same letter, thoughts regarding the post-religious world of Europe that come very close to Kearney's ideas of anatheism. ${ }^{11}$ Here, Bonhoeffer links the idea of a powerless God with the world's coming-of-age, so that a world coming into its own has been able to substitute a suffering God for the Deus ex machina that existed as a projection of a fearful humanity (Bonhoeffer 1959):

This is the decisive difference between Christianity and all religions. Man's religiosity makes him look in his distress to the power of God in the world; he uses God as a Deus ex machina. The Bible however directs him to the powerlessness and suffering of God; only a suffering God can help. To this extent we may say that the process we have described by which the world came of age was an abandonment of a false conception of God, and a clearing of the decks for the God of the Bible, who conquers power and space in the world by his weakness. (p. 164)

The point is, then, that those who want to find God must look for God among the weak, the powerless and the suffering, where he is present as weak, powerless and suffering - and this implies that the contemporary believer must engage himself or herself in complete commitment in the secular world (Mulcahy 2007; cf. Fiddes 1989:165):

Paradoxical though it may seem, the saving presence of Christ in the community of the Church or the community of the wide world is revealed in weakness and suffering, and yet possesses a power to transform the personalities of those who strive to follow him. (p. 189)

In this summary of Bonhoeffer's answer to the question of who Christ is and where he may be found, we find ourselves very close to a theological formulation of Kearney's argument for a God Who May Be that exemplifies the powerless possible. Indeed, there is great irony at the core of the revelation of the Divine in and through the human being from Nazareth. If the miracle is that God has come so close to humanity that we may only take a few steps, reach out our hands and touch God-in-flesh, then it also discloses the unspeakable

\footnotetext{
11.Bonhoeffer: 'Religious people speak of God when human perception is (often just from laziness) at an end, or human resources fail: it is really always the Deus ex machina they call to their aid, either for the so-called solving of insoluble problems or as support in human failure -always, that is to say, helping out human weakness or on the borders of human existence. Of necessity, that can only go on until men can, by their own strength, push those borders a little further, so that God becomes superfluous as a Deus ex machina. I have come to be doubtful even about talking of "borders of human existence." Is even death to-day, since men are scarcely afraid of it any more, and sin, which they scarcely understand any more, still a genuine borderline? It always seems to me that in talking thus we are only seekin genuine borderline? It always seems to me that in talking thus we are only seeking rantically to make room for God. I should like to speak of God not on the borders of life but at its centre, not in weakness but in strength, not, therefore, in man's suffering and death but in his life and prosperity. On the borders it seems to me better to hold our peace and leave the problem unsolved. Belief in the Resurrection is not the solution of the problem of death. The "beyond" of God is not the beyond of our perceptive faculties. The transcendence of theory based on perception has nothing to do with the transcendence of God. God is the "beyond" in the midst of our life' (1959:123-124).
}

vulnerability to which God opens Godself in the world. Indeed, while some hands may reach out to the God-Man in the desperate hope that a simple touch may heal a lifetime of shame and social ostracising (the woman with chronic blood flow), and some hands might reach out in an act of worship (the woman washing Jesus' feet with her tears), other hands may point fingers and shout, 'crucify him'. As Ratzinger (2004) so aptly states:

The very thing that at first seems to bring God quite close to us, so precisely, also becomes in a very profound sense the precondition for the 'death of God', which henceforth puts an ineradicable stamp on the course of history and the human relationship with God. God has come so near to us that we can kill him and that he thereby, so it seems, ceases to be God for us. (n.p.)

It is in this context that we have to take seriously the biblical symbols of judgement, punishment and death (Migliore 2004):

By contrast, hell is simply wanting to be oneself apart from God's grace and in isolation from others. Hell is that selfchosen condition in which, in opposition to God's agapic love and the call to a life of mutual friendship and service, individuals barricade themselves from others. It is the hellish weariness and boredom of a life focused entirely on itself. Hell is not an arbitrary divine punishment at the end of history. It is not the final retaliation of a vindictive deity. Hell is selfdestructive resistance to the eternal love of God. It symbolizes the truth that the meaning and intention of life can be missed. Repentance is urgent. Our choices and actions are important. God ever seeks to lead us out of our hell of self-glorification and lovelessness, but neither in time nor in eternity is God's love coercive. (p. 347)

Kearney is often criticised for proposing that possibility, which he imagines characterises the Divine as God Who May $B e$, makes both God and the divine purpose vulnerable to human choice and action. Kearney insists, namely, that it remains the human prerogative to respond negatively, or positively, to the transfiguring Spirit luring us to the eschatological future where God May Be God. We would propose, however, with Kearney, that the certainty that Christianity has often projected onto the Eschaton as a guaranteed future should pass through the purifying fires of Freud, Marx and Nietzsche. We may very well find an idol lurking in the midst of this assurance, a sublimated projection of human angst when faced with the uncertainty that characterises our existence. Kearney's anatheistic project purposefully invites faith to open itself to the necessary death of such gods of comfort and control. On the other side of our idols, we may believe again. In this perspective, God makes Godself vulnerable to humanity, by the freedom of God's own choice. This vulnerability runs both ways, however, because humans cannot but be affected by such a revelation of love in the person of Christ.

In this context, the vulnerability of God, by God's free choice, may be translated as a vulnerable outcome. Creation's future is not certain. God's intended future for creation may be, or it 
may not, depending on the free choice of humanity to respond (or not) to God's transfiguring presence, becoming co-creators of the Messianic Kingdom of justice and love. This means that the biblical symbols of judgement, punishment and death reveal the frightening reality that the 'meaning and intention of life can be missed', and that the choice to open to God's intended future is an urgent one (Migliore 2004). God's love is not coercive.

\section{Conclusion}

How is any of this relevant to the demands being placed on leadership in the public sphere today? To answer this, I need to start by pointing to a serious shortcoming of this article. Owing to mainly spatial constraints, and also to set a more simplified scene until the necessary concepts have been introduced, I have framed the leadership challenge within the parameters of ethical leadership on the one hand, and individual leadership on the other. In reality, the contemporary challenges that leadership is called to answer is far greater than this, and the idea that any individual leader, regardless of how ethical his or her leadership style may be, will solve these challenges is laughably oversimplified and idealistic. The tenacity with which complex global problems, such as those typified by the United Nations Sustainable Development Goals have persisted, and indeed gotten worse, has forced critical leadership studies to move beyond the simple answers that characterised leadership theories of yonder years and still continue to earn business schools the small fortunes that ensure their own survival. In the face of what is now termed 'super wicked problems', that is, problems with (1) alarming time constraints, where (2) the ones causing the problem also seek to provide a solution, where (3) 'the central authority needed to address the problem is weak or nonexistent' and where (4) 'policy responses discount the future irrationally' (Levin et al. 2012:123), critical leadership studies have had to move beyond the individual to inquire into leadership emergence as the multilevel interactional process driven by deep level cognitive and perceptual processes of group members that form a collective patterning of leader and follower interactions over time' (Acton et al. 2019:146).

This is why Sustainable Development Goal (SDG) 17 stresses collaboration through multi-sector partnerships as a means of implementation of the SDGs. This significantly raises the bar for leadership, and likewise also for any theological reflection aiming at a relevant contribution regarding the role of an imagination of the sacred in such a complex leadership framework, especially in the (post)secular(ising) civic context that has excluded the God-question from public discourse. Quite obviously, any attempt made in a few pages must fall short. This article should be seen as an initial attempt, a la Kearney, Fiddes and Bonhoeffer, to sketch a conceptualisation of the powerless God, pushed to the fringes, yet no less active in salvific initiative through those who may believe again. Thus, we have started with individual leaders and call for ethical leadership, but this looking glass has delivered us to the far more complex challenges of the global (post)secular(ising) world. Indeed, global humanity is marching at great speed to a judgement day of their own making, the horrors of which apocalypseauthors have only imagined. To conceptualise what it may take for the Kingdom of God to be realised in such a context, I have drawn on Kearney's God of possibility, as well as Bonhoeffer's later letters from prison, to provide theological foundation for a public spirituality of leadership, where the (post)secular(ising) world is cast in light of Bonhoeffer's description of the absence of God in the world.

A spirituality of leadership that meets the contemporary challenges must, of necessity, have its starting point in a complete commitment to the world. A la Schleiermacher, a first element to be elaborated here is that of community: a spiritual leader creates communal environments where the presence of a vulnerable God may be experienced in seeming absence. A la Bonhoeffer, a second element is a surrender of power: a spiritual leader answers a call to belong to the world in a complete surrender that resembles that of Christ stumbling to Calgary. With these two elements, we echo Fry's (2003) two core dimensions of spiritual leadership, namely, 'calling' and 'membership'. The motivations driving such leaders must remain hidden, as is God's own presence, pushed aside by a world who will have nothing of religion. And through this grand act of hospitality, receiving the world in love even as the world pushes God aside, the Kingdom may come, and all things may yet be possible with God.

\section{Acknowledgements Competing interests}

The author declares that she has no financial or personal relationships that may have inappropriately influenced her in writing this article.

\section{Author's contributions}

Y.S. is the sole author of this research article.

\section{Ethical considerations}

This article followed all ethical standards for a research without direct contact with human or animal subjects.

\section{Funding information}

This research received no specific grant from any funding agency in the public, commercial or not-for-profit sectors.

\section{Data availability statement}

Data sharing is not applicable to this article as no new data were created or analysed in this study. 


\section{Disclaimer}

The views and opinions expressed in this article are those of the author and do not necessarily reflect the official policy or position of any affiliated agency of the author.

\section{References}

'Calls for ethical leadership at breathtaking 2018 CFO Award', CFO South Africa, 11 May 2018, viewed 30 May 2018, from https://cfo.co.za/article/calls-for-ethicalleadership-at-glamourous-2018-cfo-awards.

'Country Needs Ethical Leaders', BBQ, 06 November, 2017, viewed 19 June 2019, from http://www.bbqonline.co.za/articles/country-needs-ethical-leaders-23762.html.

'Religious leaders to meet ANC top six over leadership crisis', eNCA, 08 April, 2016 viewed 19 June 2019, from https://www.enca.com/south-africa/religiousleaders-meet-anc-top-six-over-leadership-crisis.

'SA Council of Churches discusses finding of corruption report', eNCA, 18 May, 2017 viewed 19 June 2019, from https://www.enca.com/south-africa/catch-it-livesouth-african-council-of-churches-releases-corruption-report.

Acton, B.P., Foti, R.J., Lord, R.G. \& Gladfelter, J.A., 2019, 'Putting emergence back in leadership emergence: A dynamic, multilevel, process-oriented framework', The Leadership Quarterly 30(1), 145-164. https://doi.org/10.1016/j.leaqua.2018. 07.002

Barnett, T., n.d., 'Spirituality in leadership', Encyclopedia of management, viewed 30 May 2018, from http://www.referenceforbusiness.com/management/Sc-Str/ Spirituality-in-Leadership.html.

Bonhoeffer, D., 1959, Prisoner for God: Letters and papers from prison, in E. Bethge (ed.), transl. R.H. Fuller, The Macmillan Company, New York, NY.

Cronjé, J., 2017, 'Business groupings call for ethical leadership after Ramaphosa's win', Fin24, viewed 20 May 2018, from https://www.fin24.com/Economy/businessgroupings-call-for-ethical-leadership-after-ramaphosas-win-20171218-2.

Daft, R.L., 2015, The leadership experience, 6th edn., Cengage Learning, Stamford, CT.

Enblem, J.D., 1992, 'Religion and spirituality defined according to current use in nursing literature,' Journal of Professional Nursing 8(1), 41-47. https://doi. org/10.1016/8755-7223(92)90116-G

Fiddes, P.S., 1989, Past event and present salvation: The Christian idea of atonement Westminster, Louisville, KY.

Fiddes, P.S., 1992, The creative suffering of God, Clarendon Press, Oxford.

Fry, L.W., 2003, 'Toward a theory of spiritual leadership', The Leadership Quarterly 14(6), 693-727. https://doi.org/10.1016/j.leaqua.2003.09.001

Geaney, M.M., 2015, 'A spirituality leadership competency model: What does it take to be a spiritual leader in business?', Abhinava Prabandhan 3(2), 38-45.

Iheriohanma, E.B.J. \& Oguoma, O., 2010, 'Governance, leadership crisis and underdevelopment in Africa: An explorative discourse', European Journal of Socia Sciences 12(3), 409-416.

Kearney, R., 2001, The God who may be: A hermeneutics of religion, Indiana Series in the Philosophy of Religion, Indiana University Press, Bloomington, IN.

Kearney, R., 2009, 'Returning to God after God: Levinas, Derrida, Ricoeur', Research in Phenomenology 39(2), 167-183. https://doi.org/10.1163/156916409X448157

Kearney, R., 2011, Anatheism: Returning to God after God: Insurrections: Critical studies in religion, politics, and culture, Columbia University Press, New York, NY.

Kearney, R., 2018, 'Across oceans: A conversation on otherness, hospitality and welcoming a strange God', in D.P. Veldsman \& Y. Steenkamp (eds.), Debating otherness with Richard Kearney: Perspectives from South Africa, pp. 307-342, AOSIS, Cape Town. https://doi.org/10.4102/aosis.2018.BK94.15
Kgatle, M.S., 2018, 'Servant leadership: An urgent style for the current political leadership in South Africa', Verbum et Ecclesia 39(1), a1815. https://doi.org/ 10.4102/ve.v39i1.1815

Levin, K., Cashore, B., Bernstein, S. \& Auld, G., 2012, 'Overcoming the tragedy of super wicked problems: Constraining our future selves to ameliorate global climate change', Policy Sciences 45(2), 123-152. https://doi.org/10.1007/s11077-0129151-0

Madia, T., 2017, 'Council of churches report on state capture can be used in NEC discussions - Mantashe', News24, viewed 19 June 2019, from https://www. news24.com/SouthAfrica/News/council-of-churches-report-on-state-capturecan-be-used-in-nec-discussions-mantashe-20170527.

Mahlase, M., 2018, 'Churches threaten to act against Mkhwebane over state capture inquiry', News24, viewed 19 June 2019, from https://www.news24.com/ SouthAfrica/News/churches-threaten-to-act-against-mkhwebane-over-statecapture-inquiry-20180116.

Makgoba, T., 2017, Christmas sermon as reprinted in Times Live, viewed 08 January 2017, from https://www.timeslive.co.za/politics/2017-12-25-end-the-zuma-eraanglican-archbishops-christmas-wish/.

Mali, L., 2018, 'A conversation with Kimi Makwetu: Auditor General of South Africa', Conversations with Lincoln, viewed 19 June 2019, from http://www. leadershipconversations.co.za/conversations-with-leaders/a-conversation-withkimi-makwetu-auditor-general-of-south-africa/.

McCauley, R., 2016, 'Our country is in a leadership crisis', IOL, viewed 19 June 2019, from https://www.iol.co.za/the-star/our-country-is-in-a-leadership-crisis2083451.

Migliore, D.L., 2004, Faith seeking understanding: An introduction to Christian theology, 2nd edn., William B. Eerdmans Publishing Company, Grand Rapids, MI.

Mohale, B., 2019, 'Reflections on South Africa's leadership crisis', Radio interview by Eusebius McKaiser, Radio Talk 702, viewed 19 June 2019, from http://www.702. co.za/podcasts/125/the-best-of-the-eusebius-mckaiser-show/194895/ reflections-on-south-africas-leadership-crisis.

Mulcahy, E., 2007, The cause of our salvation: Soteriological causality according to some modern British theologians 1988-1998, Tesi Gregoriana: Serie Teologia 140, Editrice Pontificia Università Gregoriana, Rome.

Naudé, P., n.d., 'South Africa's leadership crisis', MBA.CO.ZA, viewed 19 June 2019 from http://www.mba.co.za/infocentrearticle.aspx?s=48\&c=11\&a=3991\&p=3.

Nhlabathi, H., 2017, 'SACC to lobby MPs', News24, viewed 19 June 2019, from https://www.news24.com/SouthAfrica/News/sacc-to-lobby-mps-20170701.

Pillay, V., 2016, 'Thuli Madonsela on faith and its role in society', Mail \& Guardian, viewed 19 June 2019, from https://mg.co.za/article/2016-03-23-thuli-madonselaon-faith-and-its-role-in-society.

Raborife, M., 2016, 'An ethical leader leaves no room for corruption - Mogoeng' News24, viewed 30 May 2018, from https://www.news24.com/SouthAfrica/ News/an-ethical-leader-leaves-no-room-for-corruption-mogoeng-20160411.

Ramaphosa, C., 2019, 'State of the Nation Address', viewed 19 June 2019, from https://www.dtps.gov.za/images/Minister/SONA-2019-by-President.pdf.

Ratzinger, C.J., 2004, Introduction to Christianity, transl. J.R. Foster, Ignatius Press, San Francisco, CA

Reave, L., 2005, 'Spiritual values and practices related to leadership effectiveness', The Leadership Quarterly 16(5), 655-687. https://doi.org/10.1016/j.leaqua.2005. 07.003

Schoeman, M., 2014, 'A crisis of leadership? Reflections on 20 years of democracy', lecture presented at the University of Pretoria, Pretoria, 05th March, viewed 19 June 2019, from https://www.up.ac.za/leaders-in-research/article/2746155/acrisis-of-leadership-reflections-on-20-years-of-democracy.

Steenkamp, Y., 2016, 'Post-metaphysical God-talk and its implications for Christian Theology: Sin and salvation in view of Richard Kearney's God Who May Be', PhD thesis, Department of Systematic and Historical Theology, University of Pretoria.

Tillich, P., 1968, Systematic theology, vol. 1, 2 \& 3, James Nisbet \& Co., Welwyn. 